\title{
VACSORA TÁLALVA! TERMÉSZETI ERÖFORRÁSOK ÉS AZ ÉLELMISZER-FOGYASZTÁS
}

\section{DINNER IS SERVED. NATURAL RESOURCES AND FOOD CONSUMPTION}

\author{
Bauerné Gáthy Andrea', Dombi Mihály², Karcagi-Kováts Andrea ${ }^{3}$ \\ ${ }^{1} \mathrm{PhD}$, adjunktus \\ 2PhD, adjunktus, dombi.mihaly@econ.unideb.hu \\ ${ }^{3} \mathrm{PhD}$, adjunktus \\ Debreceni Egyetem Gazdaságtudományi Kar Közgazdaságtan Intézet Környezetgazdaságtan Tanszék, Debrecen
}

Kulcsszavak: élelmiszer, környezetterhelés, helyi termékek, fenntartható élelmiszer-gazdaság

Keywords: food, environmental impact, local product, sustainable food system

\section{BEVEZETÉS}

Az életmódunk nélkülözhetetlen elemeként - a környezeti hatások szemszögéből - az élelmiszer-fogyasztás tekinthető a legjelentősebbnek a háztartási és közlekedési energiafelhasználás mellett. A társadalom környezetterhelésének megközelítőleg egyharmadát az élelmiszer-fogyasztás által indukált természeti erőforrás-felhasználás okozza. A világot jellemző egyenlőtlenség az élelmiszer-fogyasztásban is megfigyelhető, míg a gazdaságilag fejlett országokra a túlfogyasztás és a magas fogyasztási veszteségek jellemzők, addig a fejlődő országokban a mennyiségi és minőségi éhezés, illetve a magas termelési veszteségek az általánosak.

A fenntartható élelmiszer-fogyasztás úgy foglalható össze, mint az egészséges élethez elegendő mennyiségü és minőségü élelem biztosítása a környezetterhelés minimalizálása mellett (Auestad-Fulgoni, 2015). A problémakör megközelíthető a fenntartható étrend oldaláról is. Ez az étrend úgy jellemezhetö, mint környezetkímélő, kulturálisan elfogadható, technológiailag és gazdaságilag elérhető, egészséges, biztonságos, tápláló és optimálisan hasznosítja a természeti és humán erőforrásokat (FAO, in Macdiarmid et al., 2012).

Tanulmányunk hátterét korábbi kutatásunk szolgálja az élelmiszer-fogyasztás környezeti hatásait illetően, mely az élelmiszer-szükségletek szintjét mutatja be, valamint az élelmiszerek és az egyes étrendek környezeti hatásait elemezi széles körü nemzetközi szakirodalom felhasználásával (lásd Dombi, 
2016). Jelen tanulmányban egy, a tanszékünkön végzett felmérés eredményeiből kiindulva mutatunk rá arra, hogy az élelmiszer végső felhasználása önmagánál legalább egy nagyságrenddel nagyobb természeti erőforrás-inputot igényel; végül következtetéseket vonunk le a fenntarthatóbb élelmiszer-fogyasztásra vonatkozóan.

\section{AZ ÉLELMISZER-FOGYASZTÁS KÖRNYEZETI HATÁSAI}

Az élelmiszer-gazdaság környezeti hatásait tanulmányozva több nehézséggel is szembesülünk. Egyrészt a nagyarányú veszteség miatt nehéz olyan pontos adatbázishoz jutni, amely a ténylegesen elfogyasztott élelmiszer mennyiségét mutatja be. A makroszintủ adatokból levezetett (top-down) adatok generálása viszonylag egyszerü ugyan - ilyenek például a FAO- (Food and Agriculture Organization of the United Nations) élelmiszermérlegek (Dombi, 2016), a hazai felméréseken alapuló KSH-élelmiszermérlegek (KSH, 2017) -, de ezek csak az élelmiszerként vásárolt mennyiséget képesek feltárni. Ezzel szemben a valós fogyasztást mérő felmérések meglehetősen költség- és időigényesek (lásd Sarkadi et al., 2016).

Másrészt, mint minden környezetterhelést elemző területen, itt is nehezen dönthető el, hogy mi jellemzi azt jobban: valamilyen komplex mutatórendszer (például LCA, Life Cycle Assessment) vagy egy kiemelt szennyezés (például ÜHG, üvegházhatású gáz) vagy erőforrás-felhasználás (például termőföld). Különösen nehézzé teszi a módszerválasztást, hogy az élelmiszer-ellátásnak nagyon sokszínủ a kapcsolata a természeti erőforrások felhasználásával és szennyezésével. A mezőgazdaság jelentős hatást gyakorol a biodiverzitásra, a talajra, a vízkészletre, az élelmiszer-gazdaság egésze a nyersanyag- és energiafelhasználásra, ezáltal pedig szennyező kibocsátásai is igen jelentősek.

Általában elmondható, hogy az élelmiszer-elöállítás során a legjelentősebb környezeti hatással a mezőgazdasági termelés jellemezhető. A világ édesvízkészletének 70 százalékát az élelmiszer-vertikumban használják fel (World Resource Institute 2006, in Teisl, 2011). Az Európai Unióban a termőterület közel 70\%-a az állati takarmányok előállítását szolgálja, ami becslések szerint a mezőgazdaság által okozott biodiverzitás-csökkenés 74\%-áért felel (Leip et al., 2015).

Az Európai Unióban az egy före jutó éves élelmiszer-fogyasztás által indukált anyagfelhasználás 4000-7000 kg között van, mivel az elfogyasztott ételek elöállításának anyagigénye önmaguk tömegének nyolc-tizenkétszerese. Az anyagfelhasználás 36-48\%-a húsok, 11-18\%-a tejtermékek és 10-19\%-a gabonatermékek fogyasztásához köthetö, ezzel szemben a zöldségek és gyümölcsök anyagigénye mindössze 4-6\% (Manicini et al., 2012). 


\section{Az étrend és a környezetterhelés kapcsolata}

Arnold Tukker és munkatársai (2011) LCA-módszerrel elemezték az étrendben bekövetkezett változások komplex környezeti ajándékhatásait. Vizsgálataik alapján az étrend megváltoztatásával - a táplálkozási ajánlásoknak megfelelően - kb. 25\%-kal csökkenthetők a környezeti hatások.

Sibylle Frey és John Barett (2006) skót élelmiszer-fogyasztási adatok alapján kalkulálták az étrend ökológiai lábnyomát. Status quo esetén az étkezéshez kapcsolódó ökológiai lábnyom értéke az elemzés szerint 0,75 gha/fö, ami egészséges étrend esetén 15\%-kal lehet kevesebb, vegetáriánus étrend esetén pedig akár $34 \%$-os csökkenés is elérhetö.

Egy hazai, ezerfős mintán végzett felmérés alapján az élelmiszer-fogyasztás ökológiai lábnyoma 1,2 globális ha (gha). Az élelmiszer-fogyasztás ökológiai lábnyomának 33\%-át a húsfogyasztás okozza, ezt kibővítve egyéb állati eredetü termékkel, ez már a környezeti hatás 60\%-át okozza (Vetőné Mózner-Csutora, 2013).

Michael Lettenmeier és munkatársai (2012) négy jellemző étrendet hasonlítottak össze. A szerzők más munkái alapján fontos megjegyezni, hogy a fenntartható erőforrás-használat határa a globális átlagot tekintve $8000 \mathrm{~kg}$ /fö körül van (Lettenmeier et al., 2014). Az uralkodó finn étrend anyagfelhasználása - melynek kb. $60 \%$-a az állati termékekhez köthetö - önmagában megközelíti ezt az értéket (közel 6000 kg/fö).

\section{Környezetpolitikai kulcskérdések}

Igen hangsúlyos kérdés az élelmiszerek piacának globálissá válása miatt megnövekedett környezetterhelés. Az élelmiszerek nemzetközi kereskedelme igen intenzíven növekszik, föleg a fogyasztói igényeknek és a különböző szállítási módok csökkenő költségeinek köszönhetően (Teisl, 2011). A lokális termékek előnyben részesítése kivételesen „vonzó” a fenntartható fogyasztás által megkívánt fogyasztói magatartás szempontjából, hiszen a környezeti előnyökön kívül számos pozitív hatást tulajdonítanak a helyi termékek előnyben részesítésének (például munkahelyteremtés, vidékfejlesztés).

Sok termék kifejezetten nagy távolságot tesz meg a fogyasztóig, ami valóban növeli a fogyasztás által okozott környezetterhelést. Ezen hatás azonban egyes esetekben túlértékelt. Pierre Desrochers és Hiroko Shimizu (2008) óva intenek attól, hogy kizárólag a földrajzi távolságot figyelembe véve ítéljük meg az elfogyasztott élelmiszerek környezetterhelését. Számos példa található az ökológiai szempontból előnytelenebb helyi termékre, ha a tárolást, a hütés hosszát vagy a technológiai hőigényt (üvegház) is figyelembe vesszük (Smith et al., 2005; Edwards-Johnes et al., 2008, in Teisl, 2011). Az étrend kismértékü átalakításával el 
lehet érni olyan csökkenést a környezetterhelésben, mint kizárólag helyi termékek fogyasztásával, ugyanis a környezeti hatás sokkal inkább függ attól, hogy hogyan jön létre a termék, mint hogy milyen messzire szállítják (Engelhaupt, 2008). Ez az étrend átalakításának magasabb környezetpolitikai hatékonyságát húzza alá.

Nem kell tehát elvetni a helyi termékek fogyasztását, mivel annak számos társadalmi és gazdasági előnye van. Fontos megjegyezni, hogy a természeti erőforrások egyre nagyobb arányú túlhasznosítása jelentős mértékben a globalizációnak, a nemzetközi kereskedelem intenzív növekedésének tulajdonítható. Összefoglalva tehát, a távolabbról származó termék önmagában nem feltétlenül okoz magasabb környezetterhelést, de az intenzív nemzetközi kereskedelem lehetőséget biztosít a fogyasztás növekedésére, ami a természeti erőforrások fokozott túlhasznosításához vezet.

Hasonlóan ellentmondásos az intenzív és az ökológiai gazdálkodás megítélése (lásd Teisl, 2011). Az ökológiai gazdálkodás általában alacsonyabb környezetterheléssel jellemezhetö (Hole et al., 2005), de emellett gyakran alacsonyabb hozamokkal is (Pimentel et al., 2005). Tekintve a termőterületek szükösségét, globálisan nem valószínü, hogy ezen a fejlődési pályán megvalósítható a fenntartható élelmiszer-fogyasztás vertikuma. A precíziós mezőgazdaság nyújtotta lehetőségek viszont - mind a növénytermesztésben, mind az állattenyésztésben - alacsonyabb természeti erőforrás-ráfordítást követelnek meg növekvő hozamok mellett. Egy modern mezőgazdasági rendszerben adott a lehetőség a környezetterhelés csökkentésére, mivel a fejlődés ezen irányát éppen az alacsonyabb növényvédöszer-, mütrágya- és energiafelhasználás hívta életre.

A közepes és magas jövedelmü országokban az élelmiszer-veszteség legfőbb okai között említik a fogyasztói magatartás mellett az ellátási lánc különböző szereplöi közötti koordináció hiányát (Gustavsson et al., 2011). Ezt a veszteséget az ellátási lánc különböző pontjain globálisan 10-40\% között becsülik (Auestad -Fulgoni, 2015); Lettenmeier és munkatársai (2012) szerint ez inkább 25-50\%.

Magyarországon az Agrárgazdasági Kutatóintézet szerint évente közel kétmillió tonna élelem válik hulladékká, ami közel fele az elfogyasztott mennyiségnek. Ezen hulladékok 22\%-a keletkezik a háztartásokban. Hubert Klára és Szücs István (2017) becslése alapján csak a hulladékká vált kenyérfélék 500-650 ezer gyermek közétkeztetését fedeznék Magyarországon kenyér tekintetében.

Az élelmiszer-veszteség szinte kódolva van a gazdasági rendszerben. Fontos kérdés azonban, hogy mi a veszteségek elérhető minimuma. A fogyasztói igények miatt szükségszerúen keletkeznek veszteségek az élelmiszer-vertikumban (például zöldség-gyümölcs feldolgozás), ráadásul feltételezhetjük, hogy az ajánlásoknak megfelelö, sok gyümölcsöt és zöldséget, illetve sok összetett szénhidrátot tartalmazó étrend megkívánja a széles választék tartását az egyes termékcsoportokon belül a háztartásokban. A vásárlások viszont annál nehezebben tervezhetők, minél diverzebb az étrend. Ettől függetlenül a veszteségek csökkentésének legfőbb 
útja a háztartásokban a tudatosság és az élelmiszer-beszerzés jobb menedzsmentje (tervezés, kivitelezés, szállítás, tárolás). Ez azért is kiemelendő, mert az Európai Unióban 2012-ben 88 millió tonna élelmiszer-hulladék keletkezett (173 kg/fö), ami az EU teljes élelmiszer-termelésének a $20 \%$-a, és ennek $54 \%$-a háztartások-

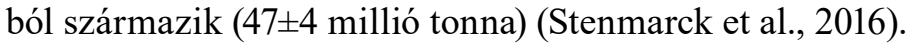

\section{A MAGYAR HÁZTARTÁSOK ÉLELMISZER-FOGYASZTÁSÁNAK TERMÉSZETI ERŐFORRÁSIGÉNYE}

A Debreceni Egyetem Környezetgazdaságtan Tanszékén 2013 és 2015 között több, a háztartások természeti erőforrás-felhasználásának megismerését célzó felmérés is folyt naplóvezetés módszerével (Dombi et al., 2015; Harder et al., 2016). A felméréseket az anyagáram-elemzés (MFA, material flow accounting) ${ }^{1}$ elveinek megfelelően végeztük, és célunk az volt, hogy a háztartások anyagfelhasználásán keresztül feltárjuk a végső felhasználáshoz kötődő természeti erőforrás-felhasználást, úgy, hogy az a háztartások társadalmi, gazdasági és egyéb jellemzőihez is köthető legyen. A továbbiakban bemutatott eredmények a 2015-ben végzett felmérés adatbázisából végzett szürésekből indulnak ki.

\section{A felmérés módszere}

A társadalmi metabolizmus alapegységének a háztartások tekinthetők, egyrészt a közös lakás határai képezik a legtöbb anyagáram fizikai határait, másrészt a különböző javak beszerzése felöli döntések is háztartási szinten születnek (Harder et al., 2016). A mintavétel során 126 háztartás fogyasztását követtük nyomon önbevallásos naplóvezetés segítségével átlagosan 14 napon keresztül önkéntes egyetemi hallgatók bevonásával. A naplók napi bontásban tartalmazzák az elfogyasztott termékek meghatározását, darabszámát és tömegét. A termékek és csomagolásuk anyagát az adatbázis felépítésekor a kutatásban közremüködők határozták meg a termékleírások alapján (1. táblázat). A vezetékes szolgáltatások felhasználását a mintavételi időszak rövidsége miatt becsültük. Az élelmiszer-fogyasztás szempontjából fontos, hogy a házon kívüli étkezéseket is tartalmazzák a naplók, ezek tömegét szakértöi becslés alapján határoztuk meg.

\footnotetext{
${ }^{1}$ A tanulmányban az anyagáram-elemzés egy input-oldali és egy felhasználási mutatóját alkalmazzuk majd. A nemzetgazdasági szintủ anyagáram-számlák egyik fő, a legátfogóbb beviteli mutatója a teljes anyagszükséglet (total material requirement, TMR) mutató, amely valamennyi beviteli áramlást tartalmazza: a hazai kitermelés, a behozatal és a fel nem használt hazai kitermelés összegeként számítható. A hazai anyagfelhasználás indikátora a DMC (domestic material consumption) a nemzetgazdaságban felhasznált összes anyagot tartalmazza a közvetett áramlások nélkül (lásd Karcagi-Kováts-Kuti, 2012).
} 
1. táblázat. A háztartások anyag-inputjai és anyagállományai

\begin{tabular}{|c|c|c|c|c|}
\hline $\mathrm{n}^{\mathrm{a}}=73$ & Átlag ${ }^{\mathrm{b}}$ & Szórás & Minimum & Maximum \\
\hline \multicolumn{5}{|l|}{ Extrapolált éves anyag-input (kg/fó) } \\
\hline Biomassza & 373,80 & 158,87 & 102 & 1093 \\
\hline Fémek & 3,34 & 13,35 & 0 & 100 \\
\hline Mủanyag & 10,19 & 15,43 & 0 & 104 \\
\hline Nemfémes ásványok & 564,27 & 4652,32 & 1 & 39780 \\
\hline Összesen, fosszilis energiahordozók nélkül & 951,61 & 4674,42 & 112 & 40318 \\
\hline Fosszilis energiahordozók ${ }^{\mathrm{c}}$ & 895,29 & 854,81 & 333 & 4253 \\
\hline Minden anyagkategória & 2159,69 & 5821,18 & 590,45 & 40897 \\
\hline \multicolumn{5}{|l|}{ Háztartási anyagállományok (kg/fő) } \\
\hline $\mathrm{Fa}$ & 211,97 & 104,57 & 44 & 540 \\
\hline Biomassza & 68,67 & 68,89 & 0 & 493 \\
\hline Müanyag & 3,85 & 4,89 & 0 & 22 \\
\hline Fém & 32,97 & 38,54 & 0 & 231 \\
\hline Nemfémes ásványok & 22,47 & 18,91 & 0 & 95 \\
\hline Kevert & 202,67 & 121,03 & 43 & 43 \\
\hline Teljes anyagfelhasználás & 536,98 & 246,90 & 102 & 1561 \\
\hline Teljes anyagfelhasználás, járművekkel & 1168,79 & 664,98 & 259 & 5033 \\
\hline $\begin{array}{l}\text { Teljes anyagfelhasználás, épített } \\
\text { anyagállományokkal }^{\mathrm{d}}\end{array}$ & 46450,68 & 28704,76 & 5082,74 & 146560,55 \\
\hline
\end{tabular}

${ }^{a} \mathrm{n}$ - a minta elemszáma

${ }^{\mathrm{b}}$ az egyes sorok egyszerủ számtani átlaga a minta alapján

c becsült $(n=47)$

${ }^{d}$ Han-Xiang (2012) alapján becsült

A társadalmi metabolizmus területének fejlődésével elötérbe került az egyes társadalmi egységek anyagáramainak (input és output flow-k) elemzése mellett az anyagállományok (stocks) vizsgálata. A fenntarthatóság szempontjából igen fontos kérdéseket vet fel a társadalom által beépített anyag mennyisége és dinamikája. Ennek megfelelően a háztartások elkészítették az ún. háztartási leltárt is. Arra kértük a részt vevő önkéntes hallgatókat, hogy a háztartásuk összes használati tárgyát mérjék fel. Amennyiben a tömeg mérésére nem volt lehetőség, a fizikai 
kiterjedés és az anyag alapján kalkuláltuk (például bútorok) vagy egyéb módon, például interneten hozzáférhető adatokkal becsültük a tárgyak tömegét (zongora, hütőgép).

A felmérés harmadik eleme a kérdőív volt, melyet a fenti két elem után töltettünk ki a háztartásokat képviselő hallgatókkal. Ezek alapvető demográfiai, jövedelmi és egyéb információkat szolgáltattak a háztartásokról. A naplóban és a leltárban található nyilvánvaló adathiány fellépése esetén egyes háztartásokat az adatok feldolgozásakor kizártunk a mintából, ilyen okok voltak például, ha egymás utáni napokon hiányzott a fóétkezés, vagy nem volt ágy a leltárban. Végül hetvenöt háztartás adatait használtuk, ez a szakirodalomban fellelhető messze legnagyobb minta hasonló kutatásokban, aminek az az oka, hogy a résztvevőktől meglehetősen nagy erőfeszítést követel meg a naplózás. Természetesen ezek az eredmények nem tekinthetők reprezentatívnak a magyar lakosságra, de az átlagot közelíthetik.

A felmérés alapján a háztartások legjelentősebb anyagáramai a fosszilis energiahordozók; az üzemanyag és a fütés az összes anyag-input közel felét teszik ki. A második legjelentősebb input a nemfémes ásványok, melyek mennyisége makroszinten is a legnagyobb a bevitt anyagok között, ezeknek több mint 90\%-a ugyanis meglehetősen nagy sürüséggel jellemezhető építőipari alapanyag.

Ha az eredmények szórására tekintünk, látható, hogy minél ritkábban fogyasztott egy bizonyos anyagcsoport, annál nagyobb a szórás. Egyes anyag-inputok felméréséhez ezzel a módszerrel tehát hosszabb mintavételi periódusra vagy más módszerre (például utólagos felmérés megkérdezéssel) van szükség.

Nem ez a helyzet a biomassza anyagcsoport esetében, itt a relatív szórás jóval alacsonyabb: $42 \%$. Ennek a csoportnak a naplók alapján átlagosan $95 \%$-a élelmiszer, melynek bevitele biológiailag determinált, és állandónak tekinthető a menynyisége, éppen ezért a naplózás módszerével pontosan mérhető.

A háztartás anyagállományai közül legjelentősebb az épületállomány, ez két nagyságrenddel haladja meg a tartós fogyasztási cikkek tömegét. Átlagosan több mint fél tonna anyag felett rendelkeznek a háztartások lakókörnyezetükben, melynek fele biomassza-eredetü, illetve közel fele kevert - ezek főleg konyhai és egyéb elektronikai eszközök.

\section{Főbb eredmények}

Statisztikailag szignifikáns eredmények alapján összességében megállapítható, hogy az anyagállományok függenek a háztartás méretétől és a jövedelemtől, de sem az állományok, sem az anyag-inputok nem függenek a környezeti attitüdtől, a család társadalmi státuszától vagy a lakóhely típusától. A háztartásméret csökkenése általános európai trend, melynek negatív környezeti hatásai ismertek: kisebb háztartások ellátásához fajlagosan több erőforrásra van szükség az ellátás 
hatékonyságának csökkenése miatt. Ez egyértelmü az anyagállomány esetében, de az input biomassza mennyisége is kismértékben függ az egy háztartásban élők számától: a korreláció gyenge-közepes $(\mathrm{r}=0,32), 90 \%$-os szignifikanciaszinten. Az összefüggés megfigyelhető az 1. ábrán is.

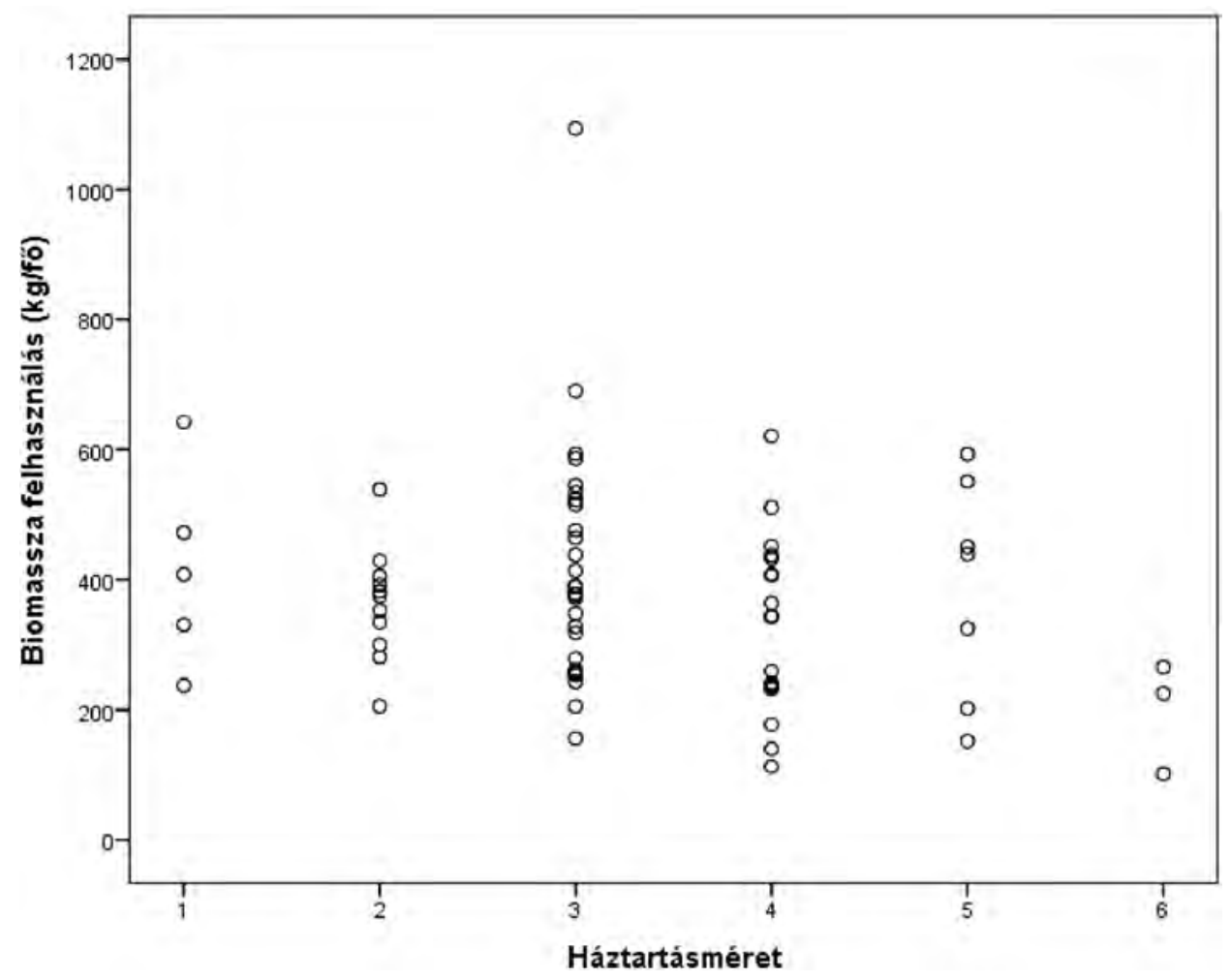

1. ábra. A háztartásméret és a biomassza-felhasználás a háztartási mintában

\section{Az élelmiszer-fogyasztás természeti erőforrásigényének jellemzése}

A makroszintű inputoknak mindössze 18\%-a jut el a háztartásokhoz végső fogyasztás céljából. Ennek az oka az egyes anyagcsoportok vizsgálatával külön-külön magyarázható. A fémek esetén a háztartások közvetlenül alacsony arányban használnak fel ilyen eredetű természeti erőforrásokat, feltehetően ezeket inkább az ipar építi be gépek és szerkezetek formájában. A nemfémes ásványok 95\%-a építőanyag-funkcióval jut be az európai gazdaságokba. Mintegy 20-30\%-a szolgál magasépítési célokat, tehát épületek építését, amelyeknek csupán fele lakóépület (Schiller et al., 2016). Ezek megjelenése a háztartásokban 10\% körüli. 
Jelentős eltérés van a háztartási minta alapján az elfogyasztott élelmiszer és az elsődleges biomassza-produkció között. Előbbi a háztartási naplókban a biomaszszacsoportnak átlagosan a 95\%-át jelenti, utóbbi pedig a hazai anyagfelhasználással (DMC, domestic material consumption) mért mutató. Az adott időszak alatt keletkezett biomasszát az MFA-adatbázisokban a természeti erőforrásokból létrehozott elsődleges terméknek tekintik, a természeti erőforrások gazdaság általi felhasználását megtestesítő indikátornak a biomassza-eredetủ termékek esetén, így az élelmiszereknél is.

Valójában az élelmiszercélú biomassza mennyisége a táblázatban találhatónál alacsonyabb, hiszen az évi 25-40 ezer tonna biomasszából kb. 3 ezer tonna faanyag. A tisztán élelmezési célokra szolgáló - közvetlenül, illetve közvetve, takarmányként - mennyiség nyomon követhető a 2. ábrán az elmúlt évtizedben Magyarországon, egy főre vetítve.

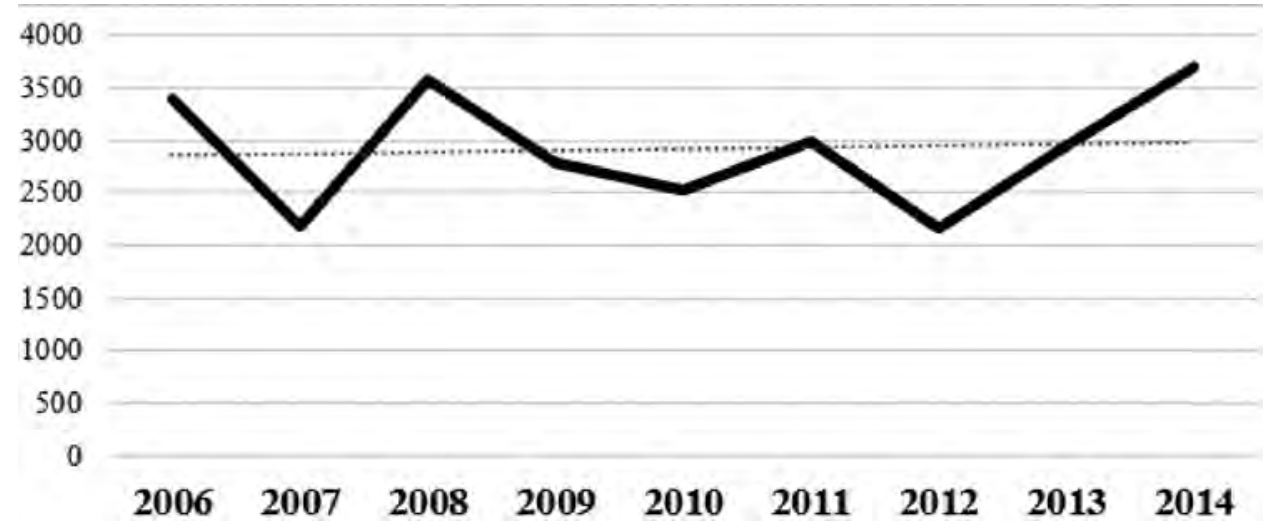

2. ábra. Az élelmiszercélú biomassza fajlagos hazai anyagfelhasználása (DMC), kg/fő

Saját szerkesztés Eurostat (URL1)

A trendvonal segítségével láthatóvá válik, hogy az évjárathatás kiszürésével fajlagosan kb. $3000 \mathrm{~kg}$ primer biomassza termelődik egy före vetítve hazánkban. Így a minta alapján az élelmiszer-fogyasztás a háztartásokban a teljes elsődleges produktum $12 \%$-a. A jelentős eltérés a makroszintủ élelmiszercélú anyag-input és a háztartási fogyasztás között három okra vezethető vissza:

- metabolikus vesztségek,

- technológiai veszteségek,

- közösségi fogyasztás.

Az első két eset tulajdonképpen a bevezető fejezetekben leírtak makroszintü felismerése. A primer növényi produkció jelentős része állati termékek felépítésében 
vesz részt, meglehetősen alacsony hatásfokkal. Az állatok testtömeg-gyarapodása során minden kilogrammnyi többlethez állatfajtól és állati terméktől függően 2-5 kg takarmányt használnak fel. Már itt találunk példát a technológiai veszteségek kialakulására is: a takarmányok segítségével felépített állati test csak kb. 60\%-ban használható fel. Természetesen a növényi termékek sem kivételek a veszteségek alól: az egyes gabonák lisztkihozatala tömegük 60-70\%-a csupán. Még ha javít is a helyzeten, hogy a melléktermékek egy részét hasznosítja az élelmiszeripar, a további feldolgozás és a kereskedelem során újabb veszteségek keletkeznek. A közösségi fogyasztás a nem háztartások által szervezett erőforrás-felhasználásra utal (például közétkeztetés).

A szakirodalmi áttekintés után azt a következtetést vonhatjuk le, hogy környezetpolitikai szempontból a leghatékonyabb út az élelmiszer-fogyasztás környezetterhelésének csökkentésére az étrend igazítása az egészségügyi ajánlásokhoz, részben az állati termékek arányának csökkentése által; illetve a veszteségek csökkentése. A közel egy a tízhez arány a végső fogyasztás és az erőforrás-felhasználás között azt is jelenti, hogy a fogyasztói döntéseknek igen nagy hatásuk van az élelmiszerek előállításához szükséges természeti erőforrások mennyiségére.

A bemutatott adatok alapján a hazai anyagfelhasználás $\mathrm{kb}$. 30\%-a élelmiszercélú biomassza. A fogyasztói szokások átalakítása - akár a veszteségek csökkentése, akár a fogyasztás racionalizálása által - jelentős előrelépést jelentene a természeti erőforrásokra nehezedő nyomás csökkentésében. Tízszázalékos élelmiszerigény-csökkenés, amely a háztartásokba bevitt anyagmennyiségnek mindössze 1,6\%-a lenne, egészségügyi szempontból is előnyökkel járna. Ez egy före vetítve 8,2\%-kal kevesebb biomassza és összességében 2,7\%-kal kevesebb természeti erőforrás felhasználását eredményezné makroszinten (DMC). Az összes természeti erőforrás felhasználásában bekövetkezett csökkenéshez hozzá kell adnunk továbbá a kevesebb biomassza előállítása által okozott csökkenést egyéb erőforrások felhasználásában. Az élelmiszercélú felhasználás a többi anyagcsoportban (fosszilis energiahordozók, fémes, illetve nemfémes ásványok) 4-7\%-ra tehetö, legmagasabb a nemfémes ásványok esetében a növényvédőszerek és mütrágyák felhasználása miatt (Dombi et al., 2015). Ezért összességében a fenti hatás a makroszintű erőforrások 3\%-ának becsülhető, ami megközelíti az évi $400 \mathrm{~kg}$ egy före jutó természeti erőforrás-felhasználást.

\section{KÖVETKEZTETÉSEK}

Jelen tanulmány célja a legújabb, fenntartható élelmiszer-fogyasztással kapcsolatos tudományos nézetek szintézise volt, törekedve a témában született tanulmányok jelentős mennyiségének feldolgozására, melyek összességét itt terjedelmi okok miatt nem mutattuk be részletesen. Ezek alapján a fenntartható élelmi- 
szer-fogyasztással kapcsolatban az alábbi, egyes esetekben bizonytalan (iii., v., vi.), további kutatást igénylő következtetések vonhatók le.

i. Az állati termékek fogyasztása - biológiai okokból kifolyólag - fajlagosan egy nagyságrenddel több természeti erőforrás-felhasználást okoz.

ii. A helyi termékekre korlátozódó étrend és az ökológiai vagy extenzív gazdálkodás önmagában nem feltétlenül jár alacsonyabb környezetterheléssel. A fenntartható étrend kialakításához más szempontokat is figyelembe kell venni (például élelmiszer-beszerzés jellemzői, élelmiszerek tárolása).

iii. Az étrend egészségügyi ajánlásokhoz való igazítása a nyugati kultúrában a környezetterhelés csökkenését eredményezné.

iv. Ugyanitt az étrendben bekövetkező változások és a háztartási élelmiszer-hulladékok mérséklödése környezetpolitikai értelemben a leghatékonyabbak, az ezekben rejlő környezetterhelés-csökkentési potenciál legalább $20-20 \%$.

v. Ezt a potenciált mindössze $10 \%$-ig kihasználva az élelmiszer-fogyasztás egy före vetítve $8,2 \%$-kal kevesebb biomassza és összességében kb. 3\%-kal kevesebb természeti erőforrás felhasználását eredményezné makroszinten (kb. $\left.400 \mathrm{~kg} / \mathrm{fo}^{\prime \prime}\right)$, mivel

vi. a hazai élelmiszer-fogyasztás mennyisége a primer biomassza-input mindössze $12 \%$-a.

\section{KÖSZÖNETNYILVÁNITTÁS}

A tanulmány megjelenését a Bognár József Közgazdaság-kutató Alapítvány támogatta.

A kutatás a „Az élelmiszer-fogyasztás természeti erőforrásigénye a társadalmi metabolizmus szempontjából" címü projekt keretében, a Nemzeti Kutatási, Fejlesztési és Innovációs Hivatal - NKFIH (K-115851) támogatásával valósult meg.

\section{IRODALOM}

Auestad, N - Fulgoni, V. L. (2015): What Current Literature Tells Us about Sustainable Diets: Emerging Research Linking Dietary Patterns, Environmental Sustainability, and Economics. Advances in Nutrition, 6, 19-36. DOI:10.3945/an.114.005694 http://advances.nutrition.org/ content/6/1/19.full.pdf + html

Desrochers, P. - Shimizu, H. (2008): Yes We Have No Bananas: A Critique of the 'Food Miles' Perspective. (Mercatus Policy Series. Policy Primer Nr. 8) Arlington: Mercatus Center https:// www.mercatus.org/system/files/Yes_We_Have_No_Bananas_A_Critique_of_the_Food_ Mile_Perspective.pdf

Dombi M. (2016): Természeti erőforrások az asztalon. A falu, XXXI, 4, 4, 11-25. 
Dombi M. - Karcagi-Kováts A. - Bauerné Gáthy A. - Kuti I. (2015): A háztartások természeti erőforrás-felhasználása, különös tekintettel az élelmiszer-fogyasztásra. Gazdálkodás, 4, 355-371. https://ageconsearch.umn.edu/record/234403/files/GAZDALKODAS_2015_04_Dombi\%20 et $\% 20$ al_355_371.pdf

Engelhaupt, E. (2008): Do Food Miles Matter? Environmental Science and Technology, 42, 3482. DOI: 10.1021/es087190e http://pubs.acs.org/doi/pdf/10.1021/es087190e

Frey, S. - Barrett, J. (2006): The Footprint of Scotland's Diet. The Environmental Burden of What We Eat. A Report for Scotland's Global Footprint Project. September 2006. http://assets.wwf. org.uk/downloads/the_footprint_of_scotlands_diet.pdf

Gustavsson, J. - Cederberg, C. - Sonesson, U. et al. (2011): Global Food Losses and Food Waste: Extent, Causes and Prevention. Rome: Food and Agriculture Organisation of the United Nations http://www.fao.org/docrep/014/mb060e/mb060e00.pdf

Han, J. - Xiang, W. N (2013): Analysis of Material Stock Accumulation in China's Infrastructure and Its Regional Disparity. Sustainability Science, 8, 4, 553-564. DOI: 10.1007/s11625012-0196-y https://www.researchgate.net/publication/257703834_Analysis_of_material_ stock_accumulation_in_China\%27s_infrastructure_and_its_regional_disparity

Harder, $\bar{R}_{\text {. }}$ - Dombi M. - Peters, G. M. (2016): Perspectives on Quantifying and Influencing Household Metabolism. Journal of Environmental Planning and Management, 60, 2, 178-203. DOI: 10.1080/09640568.2016.1142864

Hole, D. G. - Perkins, A. J. - Wilson, J. D. et al. (2005): Does Organic Farming Benefit Biodiversity? Biological Conversation, 122, 113-130. DOI:10.1016/j.biocon.2004.07.018 http://www. ecosensus.ca/hole2005.pdf

Hubert K. - Szücs I. (2017): A hazai háztartási élelmiszer-hulladékba kerülő kenyér egyes gazdasági, társadalmi és ökológiai hatásai. Gazdálkodás, 61, 1, 54-72.

Karcagi-Kováts A. - Kuti I (2012): A készletek általános elmélete és a fenntartható fejlődés. Magyar Tudomány, 173, 2, 216-225. http://www.matud.iif.hu/2012/02/13.htm

KSH (2017): Élelmiszermérlegek, a rendelkezésre álló élelmiszer mennyiségek (1970-2015). https://www.ksh.hu/4_1_2_1_hosszu

Leip, A. - Billen, G. - Garnier, J. et al. (2015): Impacts of European Livestock Production: Nitrogen, Sulphur, Phosphorus and Greenhouse Gas Emissions, Land-use, Water Eutrophication and Biodiversity. Environmental Research Letters, 10, DOI: 10.1088/1748-9326/10/11/115004/meta http://iopscience.iop.org/article/10.1088/1748-9326/10/11/115004/meta

Lettenmeier, M. - Göbel, Ch. - Liedtke, Ch. et al. (2012): Material Footprint of a Sustainable Nutrition System in 2050 - Need for Dynamic Innovations in Production, Consumption and Politics. In: Rickert, U. - Schiefer, G. (eds.): System Dinamics and Innovation in Food Networks. 584-598. http://dx.doi.org/10.18461/pfsd.2012.1242 http://centmapress.ilb.uni-bonn.de/ ojs/index.php/proceedings/article/view/1242/241

Lettenmeier, M. - Liedtke, C. - Rohn, H. (2014): Eight Tons of Material Footprint-Suggestion for a Resource Cap For Household Consumption in Finland. Resources, 3, 488-515. DOI: 10.3390/ resources3030488 http://www.mdpi.com/2079-9276/3/3/488

Macdiarmid, J. - Kyle, J. - Horgan, G. W. et al. (2012): Sustainable Diets for the Future: Can We Contribute to Reducing Greenhouse Gas Emissions by Eating a Healthy Diet? The American Journal of Clinical Nutrition, 92, 632-639. DOI: 10.3945/ajcn.112.038729 http://ajcn.nutrition. org/content/96/3/632.long

Mancini, L. - Lettenmeier, M. - Rohn, H. - Liedtke, C. (2012): Application of the MIPS Method for Assessing the Sustainability of Production-consumption System of Food. Journal of Economic Behavior and Organization, 81, 779-793. DOI: 10.1016/j.jebo.2010.12.023 https://ideas. repec.org/a/eee/jeborg/v81y2012i3p779-793.html 
Pimentel, D. - Hepperly, P. - Hanson, J. (2005): Environmental, Energetic, and Economic Comparisons of Organic and Conventional Farming Systems. BioScience, 7, 573-582. DOI: 10.1641/0006-3568(2005)055[0573:EEAECO]2.0.CO;2 https://academic.oup.com/bioscience/ article/55/7/573/306755/Environmental-Energetic-and-Economic-Comparisons

Sarkadi Nagy E. - Bakacs M. - Illés É. et al. (2016): Az Országos Táplálkozás és Tápláltsági Állapot Vizsgálat OTÁP2014 föbb eredményei. Budapest: OGYÉI, 2016. június 2. http://www.ogyei. gov.hu/dynamic/8_sarkadi_\%20otap2014_osszefoglalo_2.pdf

Schiller, G. - Müller, F. - Ortlepp, R. (2016): Mapping the Antropogenic Stock in Germany: Metabolic Evidence for a Circular Economy. Resources, Conservation and Recycling, 123, 93-107. DOI: 10.1016/j.resconrec.2016.08.007 https://www.researchgate.net/publication/306930329_ Mapping_the_anthropogenic_stock_in_Germany_Metabolic_evidence_for_a_circular_economy

Smith, A. - Watkiss, P. - Tweddle, G. et al. (2005): The Validity of Food Miles as an Indicator of Sustainable Development. Report Nr. ED50254. http://library.uniteddiversity.coop/Food/DEFRA_Food_Miles_Report.pdf

Stenmarck, A. - Jensen, C. - Quested, T. - Moates, G. (2016): Estimates of European Food Waste Levels. Reducing Food Waste through Social Innovation. FUSIONS EU Project https://www. eu-fusions.org/phocadownload/Publications/Estimates\%20 of \%20European $\% 20$ food $\% 20$ waste\%20levels.pdf

Teisl, M. F. (2011): Environmental Concerns in Food Consumption. In: Lusk, J. L. -Roosen, J. Shogren, J. F. (eds.): The Oxford Handbook of the Economics of Food Consumption and Policy. Oxford DOI: 10.1093/oxfordhb/9780199569441.013.0035

Tukker, A. - Goldboom, R. A. - de Koning, A. et al. (2011): Environmental Impacts of Changes to Healthier Diets in Europe. Ecological Economics, 70. 1776-1780. DOI: 10.1016/j. ecolecon.2011.05.001 https://www.researchgate.net/publication/227356500_Environmental_ impacts_of_changes_to_healthier_diets_in_Europe

Vetőné Mózner Zs. - Csutora M. (2013): Designing Lifestyle-specific Food Policies Based on Nutritional Requirements and Ecological Footprints. Sustainability: Science, Practice, \& Policy, 9, 2, 47-59. https://sspp.proquest.com/designing-lifestyle-specific-food-policies-based-on-nutritional-requirements-and-ecological-ac3d5c3fac37

URL1: Eurostat, http://appsso.eurostat.ec.europa.eu/nui/show.do?dataset=env_ac_mfa\&lang=en (letöltés: 2016. 11. 03.) 